SJîñn Jurnal

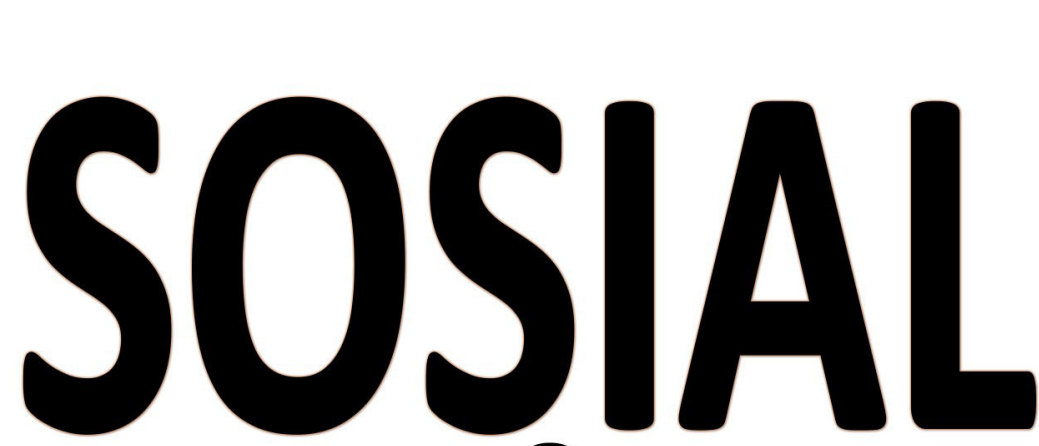

P-ISSN: 2356-1459 E-ISSN: 2654-9050 Vol. 7 No. 7 (2020)
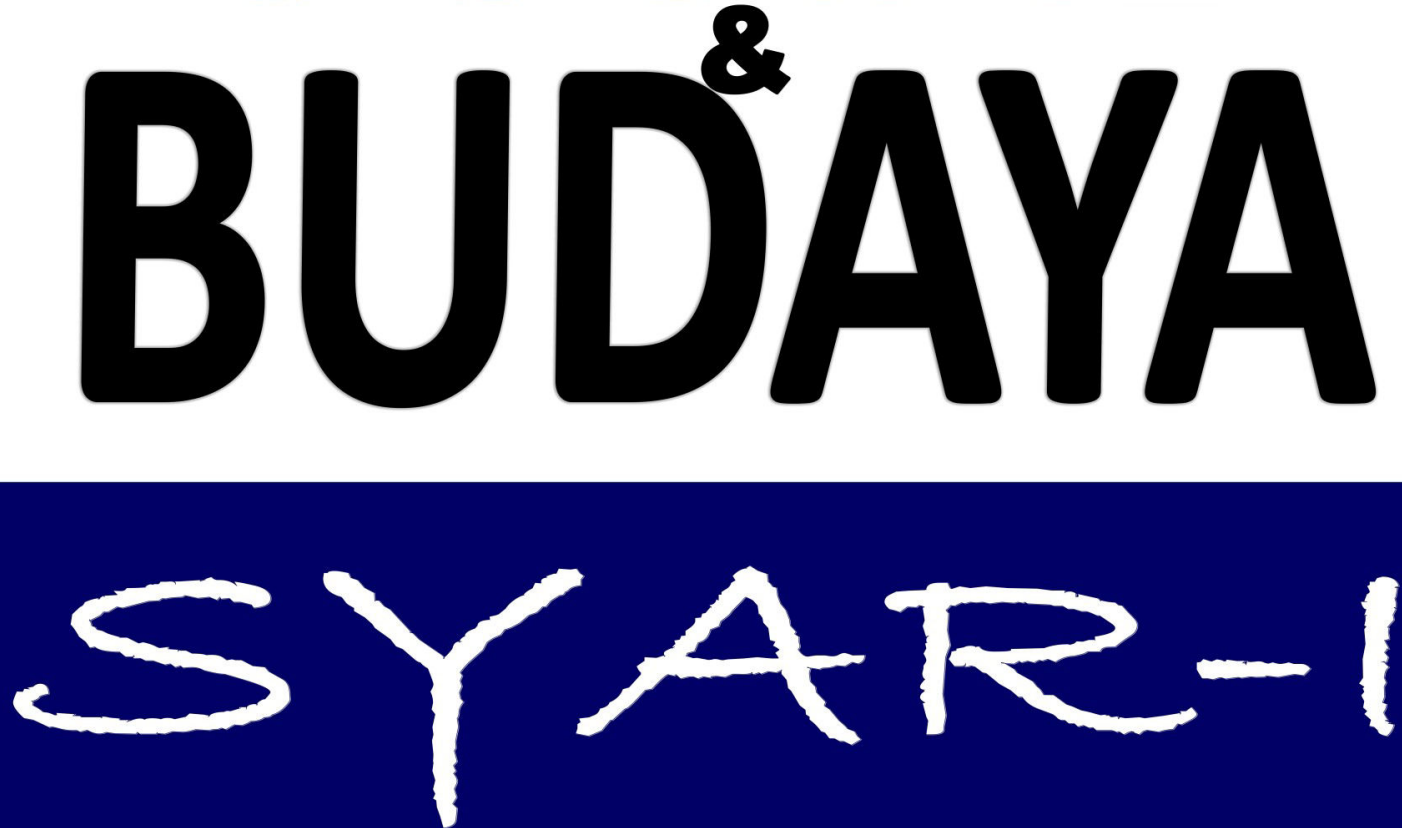

Optimasi Peran Negara Menghadapi Pandemi Corona Virus Disease 2019 dalam Perspektif Hukum Tata Negara Darurat

Rezky Panji Perdana Martua Hasibuan \& Anisa Ashari

Kedudukan Peraturan Pemerintah Pengganti Undang-Undang Nomor 1 Tahun 2020 Terkait Covid-19 Perspektif Ilmu Perundang-Undangan

Tigor Einstein, Muhammad Ishar Helmi \& Ahmad Ramzy

Konstitusionalitas Pemerintah Daerah dalam Menetapkan Kebijakan Lockdown pada Penanganan Covid-19 Raines Wadi

Peran Ekonomi dan Keuangan Sosial Islam Saat Pandemi Covid-19

Azwar Iskandar, Bayu Taufiq Possumah \& Khaerul Aqbar

Pembatasan Sosial Berskala Besar (PSBB) dan Masyarakat Berpenghasilan Rendah

Rindam Nasruddin \& Islamul Haq

Psikoterapi Spiritual dan Pendidikan Islam dalam mengatasi dan menghadapi gangguan Anciety Disorder di saat dan pasca Covid-19

Yono, Indriya Rusmana \& Hielda Noviyanty

Covid-19: Tinjauan Maqasid Al-Shariah Terhadap Penangguhan Pelaksanaan Ibadah Shalat Di Tempat Ibadah (Hifdz al-Nafs Lebih Utama Dari Hifdz al-Din?)

Hudzaifah Achmad Qotadah 


\title{
Psikoterapi Spiritual dan Pendidikan Islam Dalam Mengatasi dan Menghadapi Gangguan Anciety Disorder Di Saat dan Pasca Covid 19* Yono $^{1}$, Indriya Rusmana ${ }^{2}$, Hielda Noviyanty ${ }^{3}$ 1, 2Universitas Ibn Khaldun Bogor, Indonesia ${ }^{3}$ Universiti Kebangsaan Malaysia
} $\sigma$ 10.15408/sjsbs.v7i8.15801

\begin{abstract}
Various complaints from the public regarding anxiety caused by Covid-19 began to surface, followed by a solidarity movement to provide assistance in dealing with the effects of the Covid-19 outbreak. Education is not only interpreted as a teaching and learning process that is limited by four walls, but education is a process, where humans consciously capture, absorb, and live natural events throughout the ages. This study aims to determine the role of spiritual psychology and Islamic education, in overcoming anxiety during and after the Coronavirus Covid-19 outbreak. This research is a field research, with the type of survey research. The results of the study found that; First, spiritual psychotherapy and Islamic education have the advantage of increasing monotheism and increasing immunity in the body, by getting closer to Allah, so that they can help in overcoming and dealing with anxiety disorders in the community during and after the outbreak. Second, night bathing, repentance prayer, and evening dhikr are able to prevent, overcome, and help people deal with anxiety disorders due to Coronavirus Covid-19. Third, be kind, endeavor, and pray a lot.
\end{abstract}

Keywords: Spiritual Psychology, Islamic Education, Axciety Disorder, Covid 19

\begin{abstract}
Abstrak
Berbagai keluhan masyarakat mengenai kecemasan akibat Covid-19 mulai muncul ke permukaan, diikuti juga dengan gerakan solidaritas untuk memberikan bantuan dalam menghadapi dampak wabah Covid-19. Pendidikan tidak hanya diartikan sebagai proses belajar mengajar yang dibatasi oleh empat dinding, tetapi pendidikan adalah suatu proses, dimana manusia secara sadar menangkap, menyerap, dan menghayati peristiwa-peristiwa alam sepanjang zaman. Penelitian ini bertujuan untuk mengetahui peran psikologi spiritual dan pendidikan Islam, dalam mengatasi kecemasan disaat dan setelah wabah Coronavirus Covid-19. Penelitian ini merupakan penelitian lapangan, dengan jenis penelitian survei. Hasil penelitian menemukan bahwa; Pertama, psikoterapi spiritual dan pendidikan Islam memiliki kelebihan dengan meningkatkan ketauhidan dan meningkatkan imun dalam tubuh, dengan lebih mendekatkan diri kepada Allah Swt, sehingga mampu membantu dalam mengatasi dan menghadapi gangguan kecemasan dalam diri masyarakat di saat dan setelah wabah. Kedua, mandi malam, shalat taubat, dan zikir pagi petang mampu
\end{abstract}

*Diterima: 13 April 2020, Revisi: 24 Mei 2020, Diterbitkan 12 Juni 2020.

${ }^{1}$ Yono adalah dosen pada Prodi Hukum Islam, Universitas Ibn Khaldun Bogor, Indonesia. Email: yono@fai.uika-bogor.ac.id

${ }^{2}$ Indriya Rusmana adalah dosen pada Prodi Pendidikan Agama Islam, Universitas Ibn Khaldun Bogor, Indonesia. E-mail: indriya@fai.uika-bogor.ac.id

${ }^{3}$ Hielda Noviyanty adalah Phd student, Fakultas Psikologi, Universiti Kebangsaan Malaysia. Email: hieldahidayat86@gmail.com 
mencegah, mengatasi, dan membantu masyarakat dalam menghadapi gangguan kecemasan akibat Coronavirus Covid-19. Ketiga, berbaik sangka, berikhtiar, dan banyak berdoa.

Kata Kunci: Psikologi Spiritual, Pendidikan Islam, Axciety Disorder, Covid 19

\section{Pendahuluan}

Meluasnya wabah corona virus Covid-19 mengalami peningkatan hampir di seluruh dunia seiring berjalannya waktu. Corona virus Covid-19 memiliki dampak buruk bagi kesehatan hingga kematian. Di Indonesia perkembangan kasus Covid-19 semakin meningkat dari hari ke hari, dan menyebabkan munculnya gangguan kecemasan kepada masyarakat, terutama di kalangan remaja, sehingga dewasa. Terdapat 1.155 kasus positif, 102 meninggal, dan 59 orang yang dinyatakan sembuh sehingga 28 Maret 2020 (Detiknews). ${ }^{4}$ Menurut Mukhtar peningkatan gangguan kecemasan telah meningkat pada masa sekarang ini (Mukhtar et al. 2011) yang disebabkan oleh adanya corona virus Covid-19.

Corona virus Covid-19 memiliki dampak yang buruk bagi kesehatan tubuh manusia. Dimulai ketika penyebaran covid 19 ini bersifat carier, sehingga orang yang terkontaminasi oleh virus ini akan menjadi penyebar virus bagi manusia lainnya, melalui benda yang telah disentuhnya, udara, dan juga orang-orang yang telah kontak langsung dengan penderita Covid-19. Selain itu gejala-gejala orang yang terdeteksi terkena virus ini akan mengalami flu, batuk, pusing, demam, mual, sesak nafas, lemas, mudah lelah, seperti masuk angin sampai dengan rusaknya paru-paru. Corona virus Covid-19 merupakan suatu penyakit yang tidak terlihat wujudnya, dan bersifat carier sehingga penyebarannya pesat. Meningkatnya jumlah penderita Covid-19 ini menumbuhkan rasa kecemasan dalam diri masyarakat, dimana salah satu faktornya gejala-gejala yang dianggap ringan, dan kurangnya kesadaran dalam diri masyarakat terhadap bahaya Covid-19. Inilah yang menyebabkan adanya tekanan dan ketakutan dalam diri masyarakat belakangan ini, sehingga muncul gangguan kecemasan. Kondisi ini sangat diperlukan adanya pengobatan dari segi pencegahan, pemulihan, dan juga mengatasi kemunculan gangguan kecemasan yang berkelanjutan.

\section{Metode Penelitian}

Penelitian ini menggunakan metode penelitian kualitatif deskriptif, menganalisis mengenai peran psikoterapi spiritual dan pendidikan Islam dalam mengatasi dan menghadapi gangguan kecemasan/anxiety disorder corona virus Covid-19. Metode ini merupakan berupaya memahami berbagai konsep yang ditemukan dalam proses penelitian. Penelitian yang digunakan pada kondisi obyek yang alamiah, dimana peneliti sebagai instrument kunci, pengambilan sampel sumber data dilakukan secara purposive dan snowball, tehnik pengumpulan data dengan triangulasi (gabungan) analisis data bersifat induktif/kualitatif, dan hasil penelitian kualitatif lebih menekankan makna dari generalisasi (Sugiyono (2009: 15). Sedangkan untuk pengumpulan data peneliti menggunakan beberapa tehnik pengumpulan data

\footnotetext{
${ }^{4}$ https://news.detik.com/berita/d-4956661/data-sebaran-1155-kasus-positif-corona-di-indonesiadki-jabar-paling-banyak
} 
penelitian, yaitu observasi, wawancara, dan studi dokumentasi. kemudian data tersebut direduksi, didisplay dan disajikan sesuai dengan prosedur penelitian.

\section{Kajian Literatur}

Psikoterapi merupakan upaya pengobatan oleh terapis terhadap klien dengan melibatkan psikoanalisis untuk kesejahteraan klien dalam memahami diri (Buchanan \& Nick 2019). Secara teknik, psikoterapi mendominasi kepada proses pengobatan dengan waktu yang terbatas dan kombinasi terapi yang beragam (Corey 2009). Psikoterapi juga memiliki makna upaya pengobatan oleh terapis kepada klien yang mengalami gangguan mental dan kesulitan dalam mengendalikan diri (Laili \& Nida 2014). Disisi lain tidak hanya untuk psikoterapi, melainkan dengan adanya keterlibatan spiritual didalamnya mampu meningkatkan kualitas hidup individu (Coleman 2003). Sebagaimana dalam beberapa penelitian mengenai psikoterapi spiritual yang ternyata mampu memperbaiki peningkatan hidup dari segi mental dan juga lingkungan (Nasiri et al. 2019). Oleh sebab itu perlunya psikoterapi spiritual terhadap anxiety disorder agar dapat mengarahkan tekanan kejiwaan seseorang dengan hubungannya kepada Tuhan menjadi lebih baik (Saadeh et al. 2018).

Kesan dari psikoterapi spiritual juga di kemukakan oleh Moazedi et al dalam penelitiannya yang berdasarkan keagamaan dengan ajaran Islam berpengaruh besar terhadap kualitas hidup (Moazedi et al. 2019). Hal ini dikarenakan dalam pandangan al-Ghazali, terdapat 4 komponen spiritual yaitu al-nafs, al-qalb, al-ruh, dan al-aql manakala komponen tersebut merupakan pondasi dalam diri setiap individu (Salasiah 2016). Oleh sebab itu, menurut al-Ghazali keadaan gangguan kecemasan merupakan penyakit yang dapat diatasi dengan penyembuhan secara kerohanian (Zarrina 2001). Dalam kajian ini psikoterapi spiritual dilakukan terhadap individu yang mengalami anxiety disorder di tengah maraknya wabah corona virus covid 19 yang menginfeksi hampir diseluruh belahan dunia. Psikoterapi spiritual yang digunakan ialah dengan mandi taubat, solat taubat dan zikir. Ketiga domain tersebut memiliki kesan yang baik bagi mencegah dan mengobati anxiety disorder (Rusdi 2016, Widyastuti et al. 2019, Nugrahati et al. 2019, Abdullah et al. 2019).

Pendidikan Islam menurut Ahmad Tafsir berpendapat bahwa pendidikan agama Islam adalah bimbingan yang diberikan seseorang kepada seseorang agar ia berkembang secara maksimal seusia dengan ajaran Islam, terkandung dalam sumber dasarnya, yaitu Alquran dan Al-sunnah/hadits. ${ }^{5}$ Sedangkan menurut Ibn Khaldun di dalam buku Mukadimmah mempunyai pengertian yang cukup luas. Pendidikan bukan hanya merupakan proses belajar mengajar yang dibatasi oleh empat dinding, tetapi pendidikan adalah suatu proses, dimana manusia secara sadar menangkap, menyerap, dan menghayati peristiwa-peristiwa alam sepanjang zaman. ${ }^{6}$ Dari beberapa pengertian diatas maka dapat disimpulkan bahwa pendidikan Islam adalah usaha-usaha dalam mendidikan Islam secara terencana melalui pengalaman, pengetahuan, kecakapan, dan

\footnotetext{
${ }^{5}$ Ahmad Tafsir, Ilmu Pendidikan Islam, Bandung: Rosda, 2012

${ }^{6}$ Ibnu Khaldun, Mukaddimah, Jakarta: Pustaka Al-Kautsar, 2014
} 
keterampilan sehingga peserta didik dapat mengenal, memahami, menghayati dan mengimani ajaran Islam.

Covid-19 awalnya di duga berasal dari hewan kelelawar sebagai inangnya yang berpindah pada manusia pemakan kelelawar. Selain pendapat ini, ada juga yang mengatakan kalau Covid-19 merupakan mutasi dari virus SARS yang juga pertama kali ditemukan di Cina pada tahun 2002, yang cepat menyebar ke berbagai negara, walaupun bukan pandemi, dan kemudian virus ini bahkan sempat hilang di tahun 2004. Di Cina sendiri dalam tempo singkat perpindahan virus dari orang sudah lintas provinsi, yang berlanjut lintas negara dan kini lintas benua. Sampai akhirnya WHO pada tanggal 12 Maret 2020 telah menyatakan sebaran virus Covid-19 sebagai pandemi. Tercatat 156 negara dan telah menginfeksi sebanyak 167.740 orang, meninggal 6.456 orang, dan sembuh 76.598 orang, sedangkan 5.811orang dalam kondisi kritis. ${ }^{7}$

\section{Hasil dan Pembahasan}

Di dalam kitab Hilyatul Aulia karya Abu Nu'aim Ashfani diceritakan, suatu masa, muncul segerombolan makhluk Allah berupa wabah penyakit ganas yang hendak memasuki Kota Damaskus. Dalam perjalanan menuju Kota Damaskus, mereka bertemu dengan salah satu Wali Allah. Kemudian, terjadilah percakapan. Waliyullah bertanya, "Mau kemana kalian?" Wabah menjawab, "Kami diperintah oleh Allah untuk memasuki Damaskus." Waliyullah bertanya lagi, "Berapa lama, dan berapa banyaknya korban?" Wabah itu pun menjawab, dua tahun dengan seribu korban meninggal. Dua tahun kemudian, jumlah korban meninggal ternyata mencapai 50 ribu orang. Ketika Sang Wali bertemu kembali dengan wabah penyakit ini, ia pun bertanya, "Kenapa dalam dua tahun kalian memakan korban 50 ribu orang? Bukannya kalian janji hanya seribu orang meninggal?" Wabah itu pun menjawab, "Kami memang diperintah Allah untuk merenggut seribu korban. Empat puluh sembilan ribu korban lainnya meninggal dikarenakan panik." Dapat diambil pelajarannya juga, karena itu kepanikan justru melahirkan takdir baru yang sebelumnya belum disetting dalam qadla-Nya. ${ }^{8}$

Sebagai orang yang beriman dengan memahami dari kisah di atas kita dapat belajar dari orang-orang terbaik bersikap, apa yang dapat kita ambil ibrah atau pembelajarannya adalah:

Pertama, Mandi Taubat, merupakan salah satu proses pencegahan dan pengobatan bagi kesehatan mental yang terganggu yang salah satunya ialah gangguan kecemasan (anxiety disorder). Dalam proses mandi menggunakan air dingin akan menjadi efektif bagi kesembuhan bagi pesakit (Halimah, 2010), manakala air merupakan salah satu unsur penting yang terdapat pada tubuh manusia sebanyak $60 \%$ (Jequier et.al 2010). Dengan mandi air dingin dapat meningkatkan daya tahan tubuh

\footnotetext{
${ }^{7}$ Indriya, Konsep Tafakur Dalam Alquran Dalam Menyikapi Coronavirus Covid-19, SALAM: Jurnal Sosial dan Budaya Syar-i, 2020

${ }^{8}$ Ashfani, Abu Nu'aim, Hilyatul Aulia, Darul Fikr, Jakarta: 1996
} 
dan menguatkan sistem saraf serta meningkatkan tahap beta-endorfin dalam aliran darah (Abdullah 2019). Begitu juga air dingin berpengaruh kuat pada peningkatan metabolisme tubuh, meningkatkan konsentrasi (Mooventhan \& Nivethitha 2014). Selain itu mandi taubat dilakukan untuk menghilangkan segala penyakit baik secara fisik ataupun mental juga menggugurkan dosa-dosa (Hielda 2019). Seperti yang dijelaskan dalam Alquran surat Sad ayat 41-42:

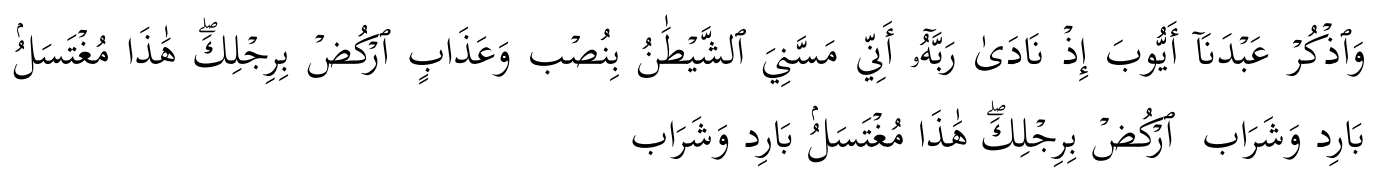

Artinya: "Dan ingatlah akan hamba Kami Ayyub ketika ia menyeru Tuhan-nya: "Sesungguhnya aku diganggu syaitan dengan kepayahan dan siksaan". (Allah berfirman): "Hantamkanlah kakimu; inilah air yang sejuk untuk mandi dan untuk minum".

Berdasarkan ayat di atas, air dingin memiliki faedah dan pengaruh yang kuat bagi kesembuhan baik fisik ataupun mental serta menjadikan pesakit lebih dekat kepada Allah Swt. Dalam kajian ini mandi taubat dilakukan diawal pagi sebelum subuh dan dalam hal ini mandi taubat dapat dilakukan oleh semua manusia untuk menjaga, mencegah dan mengobati diri dari segala penyakit. Hal ini disebabkan khasiat yang terdapat dalam kandungan air dingin pada waktu awal pagi atau sebelum subuh (Hielda \& Zainab 2019). Dengan demikian mandi taubat dapat membantu mencegah, dan mengatasi gangguan kecemasan (anxiety disorder) terhadap masyarakat di tengah wabah covid 19 sekarang ini.

Kedua, Shalat Taubat, ialah salah satu proses psikoterapi spiritual yang berasaskan kepada Alquran dan al-Sunnah. Terapi shalat taubat ini juga disebut sebagai tazkiyatun al nafs (penyucian jiwa), jika dilihat dari aktivitas spiritual dengan meminta ampunan kepada Allah swt (Salasiah 2016). Manakala shalat taubat dilakukan oleh individu dengan cara meminta ampun kepada sang Pencipta. Terapi taubat ini dapat mempengaruhi efek psikofisiologis pesakit serta mampu mengendalikan diri dengan baik Wahab \& Salam 2013). Tambahan lain shalat taubat memiliki pengaruh kuat dalam menenangkan hati terhadap gangguan kecemasan (Rusdi 2017). Hal ini disebabkan shalat taubat, atau penyucian jiwa dengan meminta ampun kepada Allah Swt, merupakan konsep psikoterapi spiritual Islam yang dapat menyembuhkan mencegah dan menenangkan gangguan kecemasan (anxiety disorder) (Musa et al. 2018). Sebagaimana telah dijelaskan dalam Alquran surat Yunus (10) ayat 57, Allah Swt berfirman:

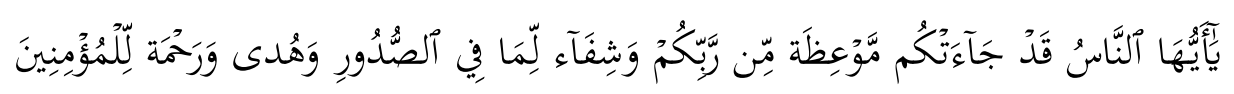

Artinya: "Hai manusia, sesungguhnya telah datang kepadamu pelajaran dari Tuhanmu penyembuh bagi penyakit-penyakit (Yang berada) dalam dada dan petunjuk serta rahmat bagi orang-orang yang beriman". 
Dalam kajian ini, aktivitas shalat taubat dilakukan pada sepertiga malam. Hal ini dilakukan karena pada waktu tersebut akan mendapatkan kelebihan yaitu kekhusyukan dan juga akan lebih tenang dalam meminta ampunan kepada Allah swt. Dengan sering melaksanakan shalat taubat, maka Allah swt akan memudahkan segala urusan termasuk kesembuhan bagi penderita anxiety disorder.

Ketiga, Dzikir, adalah mengingat Allah Swt dalam segala situasi baik susah ataupun senang. Sebab dengan mengingat Allah Swt maka akan mendapatkan ketenangan bagi pengamalnya. Hal ini terbukti dengan kajian yang dilakukan bahwa dengan mengingat Allah Swt, merupakan sebuah alternatif sebagai langkah pengobatan bagi penderita gangguan kecemasan/anxiety disorder (Ali et.al. 2018). Dzikir juga merupakan obat hati bagi segala penyakit dan mampu menurunkan gangguan kecemasan (Sulistyawati et al. 2018). Begitu juga kajian tentang gangguan kecemasan, zikir mempunyai kelebihan efektif bagi pasien yang mengalami anxiety disorder pasca operasi (Soliman \& Salwa 2013). Dzikir dalam jangka pendek telah memulihkan perasaan depresi, gangguan kecemasan (anxienty disorder) serta stres pada pasien jantung coroner (Mirzaei et al. 2015). Sebagaimana Allah telah berfirman dalam Alquran surat Ar Ra'd ayat 28:

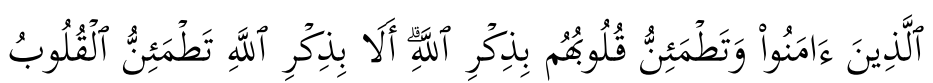

Artinya: “(yaitu) orang-orang yang beriman dan hati mereka menjadi tenteram dengan mengingat Allah. Ingatlah, hanya dengan mengingati Allah -lah hati menjadi tenteram".

Keempat, Bersabar. Di dalam sebuah hadis riwayat Imam Bukhari diceritakan, suatu kali Aisyah bertanya kepada Nabi SAW tentang wabah penyakit. Rasulullah SAW bersabda, "Wabah penyakit itu adalah orang-orang yang DIA kehendaki. Allah menjadikannya sebagai rahmat bagi orang-orang yang beriman. Jika terjadi suatu wabah penyakit, ada orang yang menetap di negerinya, ia bersabar, hanya berharap balasan dari Allah Swt. Ia yakin tidak ada peristiwa yang terjadi kecuali sudah ditetapkan Allah. Maka, ia mendapat balasan seperti mati syahid."

Kelima, Berbaik sangka dan Berikhtiarlah. Karena Rasulullah SAW bersabda:

Tidaklah Allah SWT menurunkan suatu penyakit kecuali Dia juga yang menurunkan penawarnya. (HR. Bukhari).

Keenam, Banyak berdoalah. Perbanyak do'a-do'a keselamatan, salah satu contohnya yang sudah diajarkan Rasulullah Saw untuk di lafadzkan di setiap pagi dan sore berikut ini:

"Bismillahilladzi laa yadhurru maasmihi, say'un fil ardhi walafissamaai wahuwa samiul'alim".

Artinya: "Dengan nama Allah yang apabila disebut, segala sesuatu dibumi dan langit tidak berbahaya. Dialah maha mendengar dan maha mengetahui). 
Barang siapa yang membaca dzikir tersebut 3x dipagi dan petang. Maka tidak akan ada bahaya yang memudharatkannya. (HR. Abu Dawud dan Tirmidzi). ${ }^{9}$

\section{Kesimpulan}

Dalam penulisan ini, psikoterapi spiritual dengan melaksanakan mandi taubat, shalat taubat, dan zikir mampu meningkatkan zat endorphin dalam tubuh, meningkatkan kualitas diri, menenangkan pikiran dan hati, serta mampu mencegah dan mengatasi gangguan kecemasan/anxiety disorder. Berdasarkan hasil dari beberapa penelitian yang ada menunjukkan bahwa psikoterapi spiritual dapat mencegah dan mengatasi gangguan kecemasan (Paukert et al. 2009, Unterrainer et al. 2012, Koszycki et al. 2014, Bonelli \& Koenig 2013). Psikoterapi spiritual dengan metode mandi taubat, shalat taubat dan juga zikir menunjukkan perubahan signifikan bagi gangguan kecemasan, yang dilakukan secara terus menerus.. Psikoterapi spiritual ini dilakukan sebelum subuh agar lebih efektif dalam pemulihannya. Selain itu psikoterapi spiritual ini bisa dilakukan oleh siapa pun bahkan yang non Muslim dengan menjadikannya sebagai dasar dari teknik pengobatan dan pencegahan gangguan kecemasan.

Berdasarkan pemahaman Spiritualism dan Rasionalism di dalam persfektif pendidikan Islam dapat dikatakan juga, seseorang yang memiliki tingkat spiritual tinggi, maka akan memiliki hormon endorphin yang lebih banyak dibandingkan dengan yang tingkat spiritual rendah. Secara sederhana bisa kita perhatikan pada orang yang jauh dari Allah Swt, biasanya mudah mengalami stress, pada kondisi stress hormon yang bekerja adalah adrenalin, norepinephrine dan kortisol. Hormon stress akan menyebabkan asam lambung naik, sistem imun turun, sehingga mudah terkena penyakit. Sebaliknya pada orang-orang yang beriman dan tawakal, hormon oxytocin bekerja lebih baik, sehingga akan menghasilkan endorphin yang tinggi yang menimbulkan kedamaian, ketenangan sehingga sistem imun tubuh menjadi lebih kuat. ${ }^{10}$ Dialah Allah Sang Maha Pencipta lagi Maha Mengetahui.[]

\section{Referensi:}

Abdullah, W. H. W., Hamdan, M. N., Hehsan, A., Haron, Z., Rosman, A. S. \& Ripin, mohd N. 2019. Terapi Mandi Bunga Dalam Perubatan Melayu Untuk Penjagaan Kesihatan Mental. International Journal of Islamic and civilizational Studies, 2(02), 123-135.

Ali, M. S., Ismail, M. S., Jusoh, W. H. W., Omar, S. H. S., Abdullah, M. S. \& Razak, R. A. 2018. Anxiety Therapy By Practising And Reciting Al-Fatiha Sura: An Alternative

\footnotetext{
${ }^{9}$ Indriya, Konsep Tafakur Dalam Alquran Dalam Menyikapi Coronavirus Covid-19, SALAM: Jurnal Sosial dan Budaya Syar-i, 2020

$10 \mathrm{ibid}$
} 
Remedy. International Journal of Academic Research in Business and Social Sciences, 8(7). doi:10.6007/ijarbss/v8-i7/4519

Bonelli, R.M., Koenig, H.G. Mental Disorders, Religion and Spirituality 1990 to 2010: A Systematic Evidence-Based Review. J Relig Health 52, 657-673 (2013). https://doi.org/10.1007/s10943-013-9691-4

Buana, Dana Riksa, "Analisis Perilaku Masyarakat Indonesia dalam Menghadapi Pandemi Virus Corona (Covid-19) dan Kiat Menjaga Kesejahteraan Jiwa," Salam: Jurnal Sosial dan Budaya Syar-i, Volume 7, No. 3 (2020).

Buchanan, Roderick \& Haslam, Nick. (2019). Psychotherapy (The Development of Psychotherapy in the Modern Era).

Coleman, C. L. 2003. Spirituality and sexual orientation: Relationship to mental wellbeing and functional health status. Journal of Advanced Nursing, 43(5), 457-464. doi:10.1046/j.1365-2648.2003.02743.x

Corey, G. 2009. Theory and Practice of Counseling and Phsychotherapy hlm.1-507. 8th Edisi . Belmont: Thomson higher Education.

Halimah Shuib. (2010). Petua Mak Dara. Kuala Lumpur: Perpustakaan Negara Malaysia

Jéquier, E., \& Constant, F. (2010). Water as an essential nutrient: The physiological basis of hydration. European Journal of Clinical Nutrition, 64(2), 115-123. https://doi.org/10.1038/ejcn.2009.111

Khaldun, Ibnu (2014) Mukaddimah, Jakarta: Pustaka Al-Kautsar

Koszycki, D., Bilodeau, C., Raab-Mayo, K., \& Bradwejn, J. (2014). A multifaith spiritually based intervention versus supportive therapy for generalized anxiety disorder: a pilot randomized controlled trial. Journal of clinical psychology, 70(6), 489-509. https://doi.org/10.1002/jclp.22052

Laili, F. \& Nida, K. (n.d.). Zikir sebagai Psikoterapi dalam Gangguan Kecemasan bagi Lansia. Jurnal Bimbingan dan Konseling 5(1): 133-150.

Mirzaei, Tayebeh \& Nematollahi, Monirosadat \& Sabzevari, Sakineh \& Dehghan, Saeed \& Soleymanpour, Mohamad. (2015). Short Term Effects of Islamic Zikr on Anxiety, Stress, and Depression in Mothers of Children with Congenital Heart Disease. British Journal of Medicine and Medical Research. 10. 1-5. 10.9734/BJMMR/2015/19526.

Moazedi K, Porzoor P, Pirani Z, Adl H, Ahmadi H. The Effectiveness of Islamic Teaching Based Religious-Spiritual Psychotherapy on Quality of Life, in Infertile Women. j.health. 2019; 9 (5):589-598 
Mooventhan. A., \& L. Niventhitha. 2014. Scientific Evidence-Based Effects of hydrotherapy on Various Systems of the Body. North American Journal of Medical Sciences. 6(5), 199-209.

Mukhtar, F., Oei, T. P. S., \& Yaacob, M. J. M. (2011). Effectiveness of group cognitive behaviour therapy augmentation in reducing negative cognitions in the treatment of depression in malaysia. ASEAN Journal of Psychiatry, 12(1), 50-65.

Musa, N., Yaakub, A., Muhtar, A., Mustafa, Z. \& Rashid, M. H. 2018. Psikoterapi islam menurut al- qur'an dan al -sunnah dalam mengurus tekanan pesakit kanser payudara. Journal of Social Science and Humanities, 13(2), 131-140.

Nasiri, F., Keshavarz, Z., Davazdahemami, M. H., Karimkhani Zandi, S. \& Nasirii, M. 2019. The effectiveness of religious-spiritual psychotherapy on the quality of life of women with breast cancer. Journal of Babol University of Medical Sciences, 21(1), $67-73$.

Noviyanty, Hielda. 2019. Pendekatan psikoterapi Spiritual dalam Kaunseling Pemulihan Penagih Dadah di Padepokan As Syifa Bogor. Universiti Kebangsaan Malaysia.

Noviyanty. H. \& Zainab.I. 2019. Peranan Kekeluargaan Dalam Proses Pemulihan Penagih Dadah di Padepokan As Syifa Bogor. Jurnal Pendidikan Islam, 22. 35-48.

Nugrahati, Dian \& Uyun, Qurotul \& Nugraha, Sumedi. (2018). Pengaruh Terapi Taubat dan Istighfar Dalam Menurunkan Kecemasan Mahasiswa. Jurnal Intervensi Psikologi (JIP). 10. 33-41. 10.20885/intervensipsikologi.vol10.iss1.art3.

Paukert, Amber \& Phillips, Laura \& Cully, Jeffrey \& Loboprabhu, Sheila \& Lomax, James \& Stanley, Melinda. (2009). Integration of Religion Into Cognitivebehavioral Therapy for Geriatric Anxiety and Depression. Journal of psychiatric practice. 15. 103-12. 10.1097/01.pra.0000348363.88676.4d.

Rusdi, Ahmad. (2016). Efektivitas Salat Taubat dalam Meningkatkan Ketenangan Hati. PSIKIS-Jurnal Psikologi Islami, 2(2). 2. 94-116.

Saadeh, M. G., North, K., Hansen, K. L., Steele, P., \& Peteet, J. R. (2018). Spiritual direction and psychotherapy. Spirituality in Clinical Practice, 5(4), 273-282.

Salasiah. 2016. Pendekatan kaunseling spiritual menurut al-Ghazali. Kuala Lumpur: Mahkota Enterprise.

Solaiman, Hanan \& El sayed, Salwa. (2013). Effects of Zikr Meditation and Jaw Relaxation on Postoperative Pain, Anxiety and Physiologic Response of Patients Undergoing Abdominal Surgery. Journal of Biology, Agriculture and Healthcare.. 3. 
Sulistyawati, R. A., Probosuseno, \& Setiyarini, S. (2019). Dhikr Therapy for Reducing Anxiety in Cancer Patients. Asia-Pacific journal of oncology nursing, 6(4), 411-416. https://doi.org/10.4103/apjon.apjon_33_19

Tafsir, Ahmad (2012) Ilmu Pendidikan Islam, Bandung: Rosda

Unterrainer, H.F., Lewis, A.J. \& Fink, A. Religious/Spiritual Well-Being, Personality and Mental Health: A Review of Results and Conceptual Issues. J Relig Health 53, 382-392 (2014). https://doi.org/10.1007/s10943-012-9642-5

Widyastuti, Tria and Hakim, Mohammad and Lilik, Salmah. 2019. Terapi Zikir sebagai Intervensi untuk Menurunkan Kecemasan pada Lansia. Vol 5. p147 doi 10.22146/gamajpp.13543

Yunus, N.R.; Rezki, Annissa. "Kebijakan Pemberlakuan Lock Down Sebagai Antisipasi Penyebaran Corona Virus Covid-19," Salam: Jurnal Sosial dan Budaya Syar-i, Volume 7, No. 3 (2020). 


\section{Indexed by :}
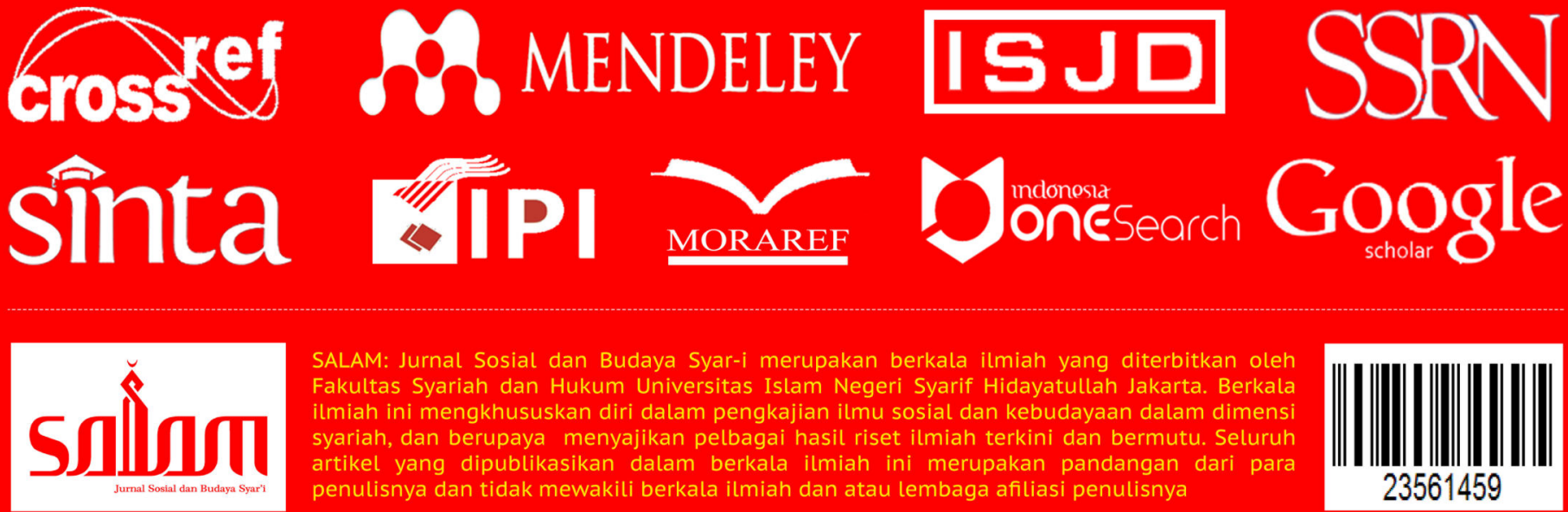

SALAM: Jurnal Sosial dan Budaya Syar-i merupakan berkala ilmiah yang diterbitkan oleh Fakultas Syariah dan Hukum Universitas Islam Negeri Syarif Hidayatullah Jakarta. Berkala ilmiah ini mengkhususkan diri dalam pengkajian ilmu sosial dan kebudayaan dalam dimensi syariah, dan berupaya menyajikan pelbagai hasil riset ilmiah terkini dan bermutu. Seluruh artikel yang dipublikasikan dalam berkala ilmiah ini merupakan pandangan dari para penulisnya dan tidak mewakili berkala ilmiah dan atau lembaga afiliasi penulisnya

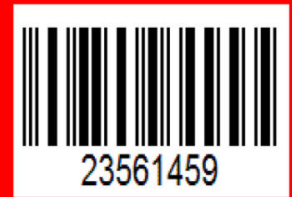

